\title{
The Functions of Non-intelligence Factors on University English Teaching
}

\author{
Lidan $\mathrm{Yu}$ \\ Huanghe Science and Technology College \\ Zhengzhou, China
}

\begin{abstract}
This paper talks about the functions of nonintelligence factors on university English teaching, and combines them with the characteristics of university English teaching. The paper discusses how to combine non-intelligence factors with English teaching and how to stimulate the students' non-intelligence factors from two aspects; the teacher-student relationship, and teaching guidance.
\end{abstract}

Keywords-functions; non-intelligence factors; university English teaching

\section{INTRODUCTION}

Non-intelligence factors play a vital role in engaging people' $s$ intelligence fully, they are the key for students to form a good successful psychology, self-learning and selfeducation ability, and are the core elements that help develop the personality of students. Non-intelligence factors include learning habits, motivation, interest, emotion, attitude and students characteristics. Cultivating a good habit of English learning is the basis of English study; to stimulate students' motivation to achieve and to cultivate their sense of achievement are the necessary means of English teaching; to train and improve students interest in learning is the effective approach to English teaching; to give emotional education to students and to have a harmonious teacherstudent relationship is the guarantee of English teaching.

\section{What IS NON-INTELLIGENCE FACTORS}

America psychologist W.P. Alexander first proposed the "non-intelligence factors" concept in Intelligence, Concrete and Abstract. Since then, many domestic and foreign experts and scholars have given their own definitions. Professor Yan Guocai's definition has great influence. He thinks generalized non-intelligence factors refer to psychological factors out of learning; the narrow sense of non intellectual factors refer to five psychological factors, they are: motivation, interest, emotion, will and personality. Linguist Rod Ellis also considers the effect of non-intellectual factors of the second language acquisition including age, talent (especially language), cognitive style, motivation and personality.

\section{SEVERAL INFLUENTIAL FACTORS OF NON- INTELLIGENCE ON ENGLISH}

\section{A. Motivation}

Human being's learning behaviors are caused by motivation. Motivation is the necessary condition of cognitive learning, but also the internal impetus of study behavior occurrence and maintenance. Canadians Gardner and Lambert divided foreign language learning motivation into "integrative motivation" and "instrumental motivation". The former refers to a learner with a special interest in the target language community, for example to participate in or integrate into the social life of community. The latter refers to a learner with a particular purpose: tests, education, travel, etc. Obviously, most people have instrumental motivation of learning English. But as long as you have a strong motivation, it can promote the English learning effectively.

\section{B. Interest}

'Interest is the best teacher' - as long as learners have great interest in the learning objective, learning motivation can be produced to improve learning efficiently until the completion of the task. Chinese great ancient educator Confucius puts forward "he who is interested in something is better than he who knows something". Russian educator Ushinski once said, "If there is no interest, students' intention to master knowledge will be killed by the obligation to study." Interest can fully arouse a learner's enthusiasm for learning participation, and improve learning efficiently.

\section{Emotion}

In English learning, emotion mainly refers to learners' feelings, attitudes and emotions within the learning process. The learner's emotion directly affects their learning behavior and results. These emotions can be divided into positive and negative. Studies by many psychologists and linguists show that self-confidence, surprise, empathy and other positive emotions can create a favorable learning attitude, and improve learning efficiency. The affective filter linguist Krashen's theory has also presented that anxiety emotion has certain influence on language input and output, and puts forward the affective filter theory. 


\section{Will}

The will is that learners want to achieve their own goals in the learning process: to adjust, control and overcome difficulties during the psychological process. Learning is hard work and students encounter various difficulties; no willpower means no strength to carry on, the objective will not be completed. Success and failure are sometimes only one step away. In the learning process, a learner's intelligence and enthusiasm is not enough, for the complex and profound learning content and tasks learners must have a strong will so they can overcome difficulties to achieve the goal.

\section{E. Character}

Personality refers to people's stable attitude and habit of behavior formed throughout their life. Psychologists have given different classifications to personality; characteristics of each personality are different. For example, extroverts actively communicate and dare to take risks; introverts are quiet, not very talkative and timid. The different characters of foreign language learners use different strategies in language learning processing. In general, extroverted learners get more input and output opportunities, but pay no attention to the form of language. They have more advantages in group learning and like to communicate with other people. But for introverted learners, because they have quiet and in-depth analysis for the input language forms, they have more advantages in language forms and rules in the teaching environment.

So how to apply these non-intelligence factors to university English teaching? The following aspects are just two examples of how this can be achieved.

\section{THE RELATIONSHIP BETWEEN TEACHERS AND STUDENTS WILL DIRECTLY AFFECT THE EFFECTIVENESS OF ENGLISH LEARNING}

"To love and respect the teacher, and then to believe what he teaches." If the relationship between teachers and students are properly handled, the students will love and respect their teachers, and then will believe the teachers' belief and guidance. Therefore, the relationship between teachers and students plays a decisive role in English teaching. As outstanding English educators, we have the obligation to try to eliminate the negative influence caused by the relationship between teachers and students in English teaching and to strengthen the positive influence. I think this is an important aspect of non-intelligence factors in the process of English teaching. In order to build favorable relationships between teachers and students, the following ideas are a good starting point:

\section{A. The correct position of the role}

At present, society has given hitherto unknown attention to education. Educational surroundings have also changed a lot: most students are an only child and parents have more demanding requirements on teachers - society has also changed its measurement, so as time has passed, the roles of teachers have also quietly changed.
As teachers of the new era, we should be aware of our changing role. To give the class to the students, the teachers should not only pay attention to the knowledge acquirement of the students, but also should pay attention to students' emotional life and. emotional experience. The teaching process should be a process of positive interaction between teachers and students, and a common development process. As teachers we should position ourselves correctly; as service providers there to help our students.

\section{B. Equal and democratic teacher-student relationship}

Teachers and students should maintain a proper distance. In the fifty's and sixty's, the image of a teacher was majestic, students were generally in awe of teachers. Nowadays, the teachers emphasize more on the importance of majesty, which may not give the students a positive experience. The students like affinity teachers, so teachers had better treat the students as our friends.

\section{To form aharmonious teacher-student ralationship}

In the process of English teaching, the classroom is the teachers' major stage; a lively and vivid English class can greatly arouse students' enthusiasm, students will also be grateful to the teacher. Therefore, teachers should carefully design each lesson, pay attention to teaching content, and differing forms of interest.

\section{The emotional exchange between teachers and students}

English teaching in the classroom is the main way to learn English, but extracurricular English activities are an extension of classroom teaching. English extracurricular activities can increase interaction between teachers and students, enhance the emotional exchange, and form a harmonious relationship between teachers and students which is good for the consolidation of English teaching. When designing extracurricular activities, the teacher should use rich teaching methods according to the physiological characteristics of the students. For example, we can take the creation of scenarios, songs, games, English corners, reading, speech contests, and so on. In the English extracurricular activities, students are the main body, the teacher plays multiple indispensable roles; teachers are not only observers, but also consultants.

\section{E. Teachers must pay attention to the students}

"All for students, for all students." With dozens of students in one class, generally speaking, it is easy for good students to get the teacher's preference. The so-called "poor students" can easily make the teacher tired. The teachers' likes and dislikes are revealed naturally, which is bound to affect the teacher-student relationship and the teaching atmosphere. The preference to the top students makes the other students have a sense of unfairness, which will affect their class emotion and may not have a positive impact on the top students. The bias on the "poor students" will not only hinder their learning, but also hurt their self-esteem. Therefore, teachers should pay attention to every student; classes with different levels of student should use different 
evaluation criteria - this evaluation will be transferred into students' learning motivation.

\section{TEACHERS SHOUld GIVE STUDENTS THE NECESSARY GUIDANCE IN ENGLISH TEACHING}

If we have a harmonious relationship between teachers and students, the students will listen to you and follow you. So as a teacher, we have the obligation to give some scientific guidance in addition to preparing lessons meticulously. I think that teachers should guide the students in the following aspects:

\section{A. Guiding students to develop good study habits, and good english learning habits include four links:}

\section{1) Preparation}

Preparation before class is the basis for students to learn a new lesson and obtain efficient learning outcomes. We should do a good job to provide a preview, so students know the score. When previewing, we should pay attention to key and difficult points, then we will have a definite object in class. This can reduce the blindness of attending a lecture, increase class effect, and improve listening efficiency. Teachers can guide students according to the situation.

\section{2) Listen carefully}

The class is the key in the process of English learning. If we miss the forty-five minutes class, after class we may take double the time, or more, to make it up. The teacher should guide the students to keep a high concentration, as far as possible, to put their hearts, ears, mouths, and hands to class, and try to memorize the lessons, new words, phrases, and sentences in class, and strive to digest the contents of the class while it is in progress.

\section{3) Revision}

Revision plays an important role in study. Even the students who listen attentively in class, because of the language discipline characteristic, can in the long term forget nine out of 10 of the language points. The teacher must guide the student to review on time. According to human forgetting law, we forget faster in a short time. An American investigation showed that if high school students review lessons shortly after class, the forgetting rate is twenty percent; if reviewing lessons after two days, the forgetting rate is fifty percent; but if a week later, the forgetting rate is seventy or eighty per cent. So if we want to learn English efficiently, we must review lessons on time.

\section{4) Practice}

Language is not obtained by teaching, but by using. We all know the math; practice makes perfect, and English is not an exception, this is the positive influence of nonintelligence factors on English learning. Through a variety of questions, and more and more training, we can consolidate the language points.

\section{B. Guiding students to adopt a scientific learning method}

In the process of teaching, teachers should guide students to adopt a more reasonable and scientific learning method, which is indispensable to the process of learning English. We can do it through the following several aspects:

\section{1) To repeat the language points again and again}

In the process of English learning, vocabulary accumulation is a difficulty that must be overcome. The teacher can suggest that students use their spare time to memorize new words, such as ten minutes before going to bed or after waking up, or/and ten minutes before and after meals. If we insist on it for a long time, the accumulation of spare time will be very considerable. You can also use small book excerpts to recite those new and easily forgotten words and phrases. In a week to a month, word memory will be no longer a problem.

\section{2) The inductive method}

In the process of language learning, using the inductive method meets the psychological characteristics and cognitive law of the students. The teacher can let the students observe the phenomenon of language, then let the students form a preliminary understanding, and then guide the students to summarize. For example, ask them to find things in common, or ask the students to summarize.

\section{3) Contrast method}

Teachers guide students to compare some similar yet different grammatical knowledge that left a deep impression on them. Such as the English language has four "said:" speak, talk, say, tell; four "static": still, quiet, silent, calm; four "hit": beat, strike, hit, knock. By comparing the usages in solving problems, students will be clear and can do a job with skill and ease.

In a word, in the process of English teaching and learning, the intelligence factors do have certain influence on the effectiveness of learning. But teachers should also be aware of the impact of non-intelligence factors on English teaching. Teachers should be good at using the attitude of enthusiasm, sincerity, high spirits and a happy mood to build a democratic, harmonious and partner type of learning platform between teachers and students. On this basis, teachers can actively provide scientific guidance to students, alleviate the burden of students, and make every student have a peaceful, joyful mood in the process of English learning.

\section{REFERENCES}

[1] Alexander, W.P. 1935. Intelligenee, Concrete and Abstraet. British Journal of Psychology Supplementary.

[2] Klashen, S.1981.Second Language Acquisition and Second Language Learning. Oxford: Pergamon.

[3] Wechsler, D. 1950.Cognitive Conative and Non-Intellective Intelligence. American Psychologist.

[4] Widdowson, H.G. 1999.Teaching Language as Communication. Shanghai: Shanghai Foreign Language Education Press. 